\title{
Object Identifier
}

National Cancer Institute

\section{Source}

National Cancer Institute. Object Identifier. NCI Thesaurus. Code C71489.

An integer or pointer that uniquely identifies an object. 